Risorgimento." An especially fortunate sequel of both of his very informative and profound lectures was the fact that older and younger members of the audience, persons who had fought in the Italian theater during World War I, as well as freshman students, engaged in a public discussion which led to a fruitful exchange of ideas from which both groups learned considerably.

University of Graz

ALEXANDER NOVOTNY

\title{
Studies in Modern History at the Historical Institute
}

In view of the fact that ever since the time of Leopold von Ranke the era of absolutism has been the field of modern history in which the most research has been done, the members of the Historical Institute at the University of Graz, especially those in charge of the classes in Austrian and general modern history, have felt it necessary to place more emphasis on the periods preceding and following the age of absolutism, particularly on the following three: (1) the sixteenth century, from Maximilian I to Archduke Charles II (in part, in connection with the 1964 jubilee!); (2) the Vormärz era in Austria and Europe (the age of Archduke John), from approximately 1780 to 1860 ; and (3) the Francis Joseph era and the end of the Austro-Hungarian monarchy.

Lack of space prevents us from mentioning all the writings of the younger historians. Fully aware that this report is too short, we are limiting ourselves to making a concise summary of the more important works which were embarked upon.

In the first group there is a whole series of special investigations of problems dealing with the era of Emperor Maximilian (recently around a dozen), among which the dissertations of Mrs. Inge Friedhuber and Roland Schäffer are especially worthy of emphasis. Mention should also be made of the studies made of Maria, Duchess of Bavaria, Archduchess of Austria, and Archduke Charles II's wife, by Hanna Wehner; Archduke Charles II's children, by Elke Roth; the youth of Emperor Ferdinand II, by Mrs. Gugl; and the relations between the courts at Munich and Graz at the end of the sixteenth century, by Günther Cerwinka.

The following studies fall into the second group: Archduke 
John and Zahlbruckner, by Josef Wagner; Archduke John and Hammer-Purgstall, by Gertraud Grossmann; Archduke John and his significance for the journalism of his times, by Peter Strallhofer; and the fundamental principles of "feudal" conservatism in Old Austria: the world image and development of Count Leo von Thun, by Christoph Thienen-Adlerflycht (a very noteworthy piece of research).

Group III includes a very informative work by Alfred Ableitinger on Rudolf Sieghart and his activities in the presidency of the ministerial council; a detailed and careful analysis of the structure and function of the Austrian society around 1878, by Mrs. Erentrude Thurner; and an excellent work, which has been recommended for a prize, on the Styrian representatives in the Austrian parliament from 1907 to 1918, by Mrs. Ulrike Melliwa-Dekitsch.

The above investigations were supervised in the regular way through mutual agreement by Vice Chancellor and Professor Wiesflecker (Austrian history) and Prof. Novotny (general modern history). Valuable advice and other help was given for the studies dealing with the era of Archduke Charles II by Docent Berthold Sutter; for those on the era of Archduke John, by Hofrat Viktor Theiss; for those on the history of settlements and education, by Prof. Fritz Posch; for those on economic history, by Prof. Tremel; for those on the history of Carinthia, by Prof. Moro; and on all works which dealt with Austrian problems, by Hofrat Klein and Docent Mezler-Andelberg.

Styria and Graz have provided very favorable soil for studying and interpreting themes involving a close connection between the problems of local, Austrian, and world history on the basis of historical research methods. Since the fall of 1961 an excellent public educational institute has existed for discussing topics dealing with a period which is especially dear to the hearts of Styrians-the era of Archduke John. In concert with the Graz "Urania," a group of university professors organized a special study group under their supervision. During the course of four years this group has organized sixty evening lecture and discussion sessions. 